Marta GALANT, Barbara SOKOLNICKA, Natalia SZYMLET, Jerzy MERKISZ Poznan University of Technology (Politechnika Poznańska)

\title{
RISK ASSESSMENT FOR FLIGHT IN UNCONTROLLED AIRSPACE UNDER VISUAL FLIGHT RULES
}

\author{
Ocena ryzyka zagrożeń $w$ locie \\ w przestrzeni niekontrolowanej według przepisów \\ dla lotów $\mathrm{z}$ widocznością VFR
}

\begin{abstract}
The paper attempts to assess the risk in the area of analysis which is the flight of general aviation (GA) aircraft carried out under Visual Flights Rules in the uncontrolled airspace. The flight, selected for further analysis, is a typical air operation performed in GA. The risk assessment was carried out in accordance with the risk management algorithm. The identification of hazard sources was made using a checklist of 123 questions about their occurrence. On this base a list of 37 threats identified in the presented area of analysis was obtained. The risk assessment was carried out by the MICE-RISK method. Among the defined threats, 16 threats fall into the accepted category, 15 threats are characterized by the tolerated category, and for 6 threats the category is defined as unaccepted. A dealing with risk methods were proposed. The re-evaluation indicated that the number of threats in particular categories are: 27, 6 and 6.
\end{abstract}

Keywords: risk assessment, hazard source, general aviation, risk management

Streszczenie: $W$ pracy podjęto próbę oceny ryzyka zagrożeń $w$ obszarze analiz, jakim jest lot samolotu lotnictwa ogólnego (GA) wykonywany zgodnie z przepisami VFR w przestrzeni niekontrolowanej. Wybrany do dalszych analiz lot jest typowa operacja lotnicza wykonywana $w$ GA. Ocene ryzyka przeprowadzono zgodnie z algorytmem zarzadzania ryzykiem. Rozpoznania źródel zagrożeń dokonano za pomoca listy kontrolnej zawierającej 123 pytania o ich występowanie. Na ich podstawie zdefiniowano 99 źródel zagrożeń, a nastepnie 37 zagrożeń rozpoznanych $w$ prezentowanym obszarze analiz. Ocene ryzyka przeprowadzono metoda MICE-RISK. W'śód zdefiniowanych, 16 zagrożeń mieści się w kategorii ,akceptowane”, 15 zagrożeń cechuje kategoria „tolerowane”, a 6 zagrożeń określono jako nieakceptowane. Zaproponowano postępowanie wobec ryzyka. Ponowna ocena wskazała, że liczby zagrożeń w kolejnych kategoriach wynosza: 27, 6 oraz 6.

Słowa kluczowe: ocena ryzyka zagrożeń, źródła zagrożeń, lotnictwo ogólne 


\section{Introduction}

Air transport is the youngest and most dynamically developing branch of transport. However, its development does not concern only commercial and passenger transport. More and more attention and interest is devoted to recreational and sports aviation. General aviation has become almost universally available. Increasing traffic in the vicinity of airports generates the need to ensure the implementation of air navigation processes with accepted or at least tolerated risk of threats in an increasingly complex air traffic management environment. Current regulations require the development of Safety Management Systems in aviation organizations (SMS) and the development and implementation of the State Safety Program (SSP) in the country.

The analysis of the number of events showed significant differences between Commercial Air Transport (CAT) and General Aviation (GA). Based on ULC and PKBWL data, it was noted that $[2,4]$ :

- $90-100 \%$ of aviation accidents take place in the GA sector,

- $65-75 \%$ of serious incidents occur in the GA sector,

- $70-75 \%$ of incidents take place in the CAT sector,

- $80-90 \%$ of notifications are generated in the CAT sector.

Therefore, it was decided to limit the area of analyzes to GA sector. It is assumed that it covers all air traffic (private and commercial), excluding scheduled and military flights [5]. Annex 6 to the Convention on International Civil Aviation, however, stipulates that general aviation operations are operations using aircraft other than those performed by commercial air transport or air services. Detailed classification of GA is conducted by the European General Aviation Safety Team (EGAST), which is one of the pillars of the European Strategic Safety Initiative (ESSI) operating at the European Aviation Safety Agency (EASA). The team points out that general aviation is a dispersed and extensive community formed by a wide variety of components, such as business aviation, aerial work, sports (competitive) aviation or recreational aviation [1]. In sports and recreational aviation can be further distinguished airplanes, balloons, gliders and ultralight aircraft flights as well as parachutes or hang gliders and sky-surfing.

GA flights, unlike scheduled ones, can take place not only in controlled airspace, but also in uncontrolled one. This leads to difficulties in the full-scale representative of air traffic in this sector, since it is not required to submit a flight plan and the report after it is taken. The only reliable indicator of the development of aviation in the uncontrolled airspace are statistics of the Flight Information Services (FIS). However, it should be remembered that the pilot has no obligation to establish communication with the service, hence it is not possible to estimate the 
actual number of flight operations. The Polish Air Navigation Services Agency (PANSA) in its statistics counts air operations understood as a record of correspondence at any time during the flight. Therefore, the take-offs and landings or temporary exits from the uncontrolled zone are not separated. Every year, the FIS service handles around 200,000 flights [8]. The polish Flight Information Region (FIR Warszawa) is divided into five sectors of FIS. These include: Poznań, Gdańsk, Warsaw, Olsztyn and Kraków. The largest number of operations is recorded in the Poznan sector.

In the further part of the article an attempt will be made to assess the risk of threats in the area of analysis which is the flight of general aviation aircraft performed in accordance with the regulations for flights with visibility (VFR) in the uncontrolled airspace. After presenting the characteristics of the analysis area, the hazard risk assessment will be carried out.

\section{Presentation of the analysis area}

As the area of analysis, the flight of general aviation aircraft in the uncontrolled airspace over the territory of the Republic of Poland, in accordance with the regulations for flights with visibility (VFR) was adopted. Therefore, the area of analyzes has been divided into sub-areas in which the sources of threats are identified. Thus, in the analysis area, sub-areas such as:

- the aircraft,

- air space,

- aeroclub airport,

- Flight Information Service,

- pilot.

\section{The aircraft}

In Poland, under the provisions of the Act of 3 July 2002 Aviation Law aircraft inventory conducted by the President of Civil Aviation Authotity (in Poland ULC) [9]. The aircraft register includes airplanes, helicopters, sailplanes, powered sailplanes, airships, balloons and unmanned aerial vehicles with a mass exceeding $25 \mathrm{~kg}$ [9]. At the beginning of January 2019, there were 2,748 aircraft in the Polish registry, and another 1,038 in the register. Each year, the number of aircrafts entered into the register increases by approximately $3 \%$. Due to the selected area of analysis, the most commonly used aircraft in Polish general aviation were subjected to further analysis. Based on the analysis of data from the aircraft register, it was recognized that the most frequently used aircraft in Poland is the Cessna aircraft - models 150 and 152. Both are very similar - they are single-engine, two-seater, metal buckling underarms adapted for 
general use, equipped with fixed three-wheeled chassis with front wheel [3]. There are slight visual and technical differences. From the point of view of safety analysis, these differences are so small that they can be averaged and the analysis will be correct for both types of aircraft. Based on the Instructions for Use in Flight [3], the hazard sources for the selected aircraft are specified.

\section{Airspace}

According to the Aviation Law, Polish airspace is divided into controlled and uncontrolled airspace [9]. The analyzed flight takes place below FL095, so in uncontrolled space. It has a class $\mathrm{G}$, which means that separation is not ensured for any flights, but the information service is available. In the process of identifying sources of threats, elastic structures in space will be particularly important. These include: prohibited areas (P), dangerous zones (D), restricted zones (R), temporary separated areas (TSAs), temporary reserved areas (TRA) and exercise areas (EA).

The regulations divide flight procedures into: Visual Flight Rules (VFR) and Instrument Flight Rules (IFR) flights. VFR flights must be carried out in compliance with the strictly defined rules regarding weather conditions VMC (Visual Meteorological Conditions) and the manner of performing such flights. It is unacceptable to lose the visibility of the Earth's surface. In aero-club flights, VFR flights are performed more often - hence their choice for further analysis.

\section{Aeroclub airport}

There are 62 items in the Civil Airports Register: certified public use airports (14), public use airports with limited certification (8), public airports that are not subject to certification (21) and exclusive use airports (19). For the purpose of the analysis, it was decided not to limit itself to a specific airport or landing ground. Analyze will be carried out for an overview of the model airport. Thanks to this treatment, the universality of the analysis will be preserved if the model is used in other conditions.

\section{Flight Information Service (FIS)}

The state agency responsible for managing the national airspace (FIR Warszawa) is the Polish Air Navigation Services Agency (PANSA). According to the Act, the Agency provides safe, continuous, smooth and effective air navigation in the Polish airspace by performing the functions of institutions providing air navigation services, airspace management and air traffic flow management.

In the uncontrolled space, the Flight Information Service FIS is provided. This is a service provided to pilots free of charge. The service is performed for VFR and IFR flights 24 hours a day. The use of the flight information service does not absolve the pilot-in-command of the aircraft from any responsibility and shall be responsible for 
the final decision as to the proposed flight plan change. The flight information service provides flight and other information that may affect safety. FIS does not ensure separation of aircraft, but can provide information about other air traffic near the aircraft. Establishing communication with the FIS is not mandatory.

\section{Pilot}

In order to characterize a group of general aviation users, a report of the number of valid licenses issued by the Aviation Personnel Registry operating at ULC [2] was used. As an elected representative of a group of private pilot (PPL) and recreational (LAPL) authorized to fly the aircraft. At the end of 2018, the number of valid licenses was 4,854 and 29 respectively. The Civil Aviation Authority, however, does not keep statistics on the age of pilots authorized to fly. The LAPL (A) license holder shall be authorized to carry out the activities of the pilot of a single-engine piston aircraft or TMG with a maximum certificated takeoff mass of $2000 \mathrm{~kg}$ or less, carrying a maximum of 3 passengers in such a way that there are never more aircraft on board an aircraft than 4 people [9].

The holder of the PPL (A) license is entitled to perform the duties of the pilotin-command or the second pilot of aircraft or TMGs in non-commercial operations [9]. It should be added that the PPL (A) license entitles to perform without remuneration functions: pilot-commander of the unused airplane for a fee and the second pilot - on all aircraft that are not used for a fee. These rights apply to singleengine aircraft with a take-off mass up to $5,700 \mathrm{~kg}$, on the VFR rules.

\section{Identifying sources of hazards and formulating hazards}

To make a checklist of questions about the sources of hazards, the risk analysis area was divided, as described in its characteristics. The most questions about the occurrence of hazards sources concern the pilot of the aircraft (44 questions). Positive answers can be obtained both in questions about the psychophysical state of the pilot as well as about his qualifications and skills. The second group of questions are those related to the Flight Information Services FIS, airport staff and other persons who may affect flight safety (18 questions). The third, extremely important group of questions concerns the technical condition of the aircraft, the current review, difficulties in the cockpit, etc. (25 questions). Due to the fact that there is a model airport in the analysis area, it was necessary to include a group of questions related to the available infrastructure, facilities or difficulties (20 questions). The last of the defined groups is the one regarding environmental conditions (16 questions). Not only atmospheric conditions, but also the possibility of industrial air pollution, etc. were taken into 
account. Generally speaking, this group concerns all issues on which the pilot and people in his immediate environment have no influence. The identification sources of hazards was carried out by answering the questions contained in the checklist. The entire list of control questions contained 123 questions, and its section (with answers) is shown in fig. 1.

In accordance with the risk management algorithm, the identification of hazard sources was based on separating from the list of questions those in which the answer was in the critical field (marked blue). The list of identified hazard sources contains 99 items. Based on their list, it was possible to formulate threats. Threat is understood as a conditional possibility of revealing losses as a result of activation of the source of threats. Formulating hazards can be understood as a way of expressing and recording events that may bring such losses in the area of analysis.

The defined hazards are divided into 6 groups:

- hazards related directly to the pilot (5 hazards),

- hazards occurring before the flight (7 hazards),

- hazards related to the start phase (4 hazards),

- hazards related to the flight phase (13 hazards),

- hazards associated with the landing phase (6 hazards),

- hazards occurring after the flight (2 hazards).

\begin{tabular}{|c|c|c|c|}
\hline \multirow{2}{*}{ No. } & \multirow{2}{*}{ Control questions about the occurrence sources of hazards } & \multicolumn{2}{|c|}{ Answer } \\
\hline & & YES & $\mathrm{NO}$ \\
\hline \multicolumn{4}{|c|}{ QUESTION GROUP 1 - PILOT } \\
\hline 1.1 & $\begin{array}{l}\text { Is it possible that the pilot is not in good physical and mental } \\
\text { condition? }\end{array}$ & $\mathbf{X}$ & \\
\hline$\ldots$ & & & \\
\hline 1.44 & $\begin{array}{l}\text { Is it possible to change flight parameters due to unconscious pilot } \\
\text { action? }\end{array}$ & $\mathbf{X}$ & \\
\hline \multicolumn{4}{|c|}{ QUESTION GROUP 2 - FIS SERVICE } \\
\hline 2.6 & $\begin{array}{l}\text { Is there a possibility of a lack of understanding of messages } \\
\text { between the pilot and the FIS }\end{array}$ & $\mathbf{X}$ & \\
\hline$\ldots$ & & & \\
\hline \multicolumn{4}{|c|}{ QUESTION GROUP 4 - AIRPORT INFRASTRUCTURE } \\
\hline$\ldots$ & & & \\
\hline 4.4 & Is there a possibility of colliding with an obstacle during the start? & & $\mathbf{X}$ \\
\hline 4.5 & Is there a possibility of colliding with an obstacle while taxiing? & $\mathbf{X}$ & \\
\hline 4.6 & Is there any certainty that airport obstacles are well marked? & $\mathbf{X}$ & \\
\hline$\ldots$ & & & \\
\hline
\end{tabular}

Fig. 1. Elements of the question checklist about the occurrence sources of hazards 


\section{Risk estimation and evaluation}

The MICE-RISK method was selected for risk assessment. It is a proprietary, qualitative method of risk assessment, allowing for detailed determination of its level, taking into account both the probability of occurrence of an event and losses that its occurrence may generate [6,7]. For each defined hazard, appropriate variables were assigned that characterize the level of probability of occurrence of damage and the level of damage generated by the activation of the threat. An example of estimating the risk of threats in flight with visibility in the uncontrolled airspace is presented below.

Hazard: Possibility of pilot fainting caused by its bad condition

Variables: $\mathrm{K}_{1}=3 ; \mathrm{K}_{2}=5 ; \mathrm{K}_{3}=5$

Calculation of the risk indicator value: 29

Risk level: significant

Risk category: tolerated

Among the defined hazards, 3 have reached the risk level defined as very large, 3 as large, 15 significant, 12 as low, and 4 as negligible. After the categorization of risk, the following results were achieved: 16 threats fall into the accepted category, 15 threats are characterized by a tolerated category, and for 6 threats the category is defined as unacceptable. Unacceptable risk is the risk area in which the system should not be allowed to operate under any circumstances. If the estimated risk is in this category, action to reduce the risk should be taken immediately. If the assessed risk is included in the tolerable risk category, preventive measures should be taken to reduce the risk or remove sources of hazard, and the level of risk should be monitored. Accepted risk is a risk area that is not significant or widely accepted without the need to take any mitigating measures, it may be possible to stop reducing its level, but risk control (monitoring) should be continued [7].

\section{Dealing with risk}

The final step in the risk management algorithm is dealing with risk. This term shall include the seizure of an active attitude towards the risks identified in the area of analysis. In order to choose the appropriate method of dealing with the risk, it was decided to analyze the results of the risk assessment. 
Table 1

List of hazards for which the level of $K_{1}$ was reduced as a result of the pilot monitoring system and supporting its work in a situation of cognitive deficits, where: A - accepted risk, $\mathbf{T}$ - tolerated risk, $\mathbf{N}$ - unacceptable risk

\begin{tabular}{|c|c|c|c|c|c|c|c|c|c|}
\hline \multirow[b]{2}{*}{ No. } & \multirow[b]{2}{*}{ The possibility... } & \multicolumn{2}{|c|}{ K1 } & \multirow[b]{2}{*}{$\mathbf{K 2}$} & \multirow[b]{2}{*}{$\mathbf{K 3}$} & \multicolumn{2}{|c|}{$\mathbf{R}$} & \multicolumn{2}{|c|}{$\begin{array}{c}\text { Risk } \\
\text { category }\end{array}$} \\
\hline & & 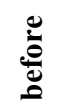 & 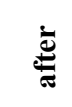 & & & $\frac{0}{0}$ & 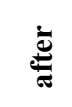 & $\frac{0}{0}$ & 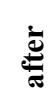 \\
\hline 1. & $\begin{array}{l}\text { fainting caused by the pilot's } \\
\text { poor state }\end{array}$ & 3 & 0.1 & 5 & 5 & 29 & 20.3 & $\mathrm{~T}$ & A \\
\hline 2. & $\begin{array}{l}\text { collision with a ground } \\
\text { obstacle }\end{array}$ & 10 & 3 & 5 & 1 & 42 & 21 & $\mathrm{~T}$ & A \\
\hline 3. & $\begin{array}{l}\text { damage to someone else's } \\
\text { property as a result of pilot } \\
\text { error }\end{array}$ & 6 & 1 & 5 & 1 & 30 & 15 & $\mathrm{~T}$ & A \\
\hline 4. & $\begin{array}{l}\text { damage as a result of events } \\
\text { initiated by other objects }\end{array}$ & 6 & 1 & 5 & 1 & 30 & 15 & $\mathrm{~T}$ & A \\
\hline 5. & $\begin{array}{l}\text { collision of two aircrafts at } \\
\text { the airport }\end{array}$ & 1 & 0.1 & 20 & 10 & 63 & 60.3 & $\mathrm{~N}$ & $\mathrm{~N}$ \\
\hline 6. & $\begin{array}{l}\text { occurrence of an incident } \\
\text { during take-off }\end{array}$ & 6 & 1 & 5 & 5 & 38 & 23 & $\mathrm{~T}$ & A \\
\hline 7. & $\begin{array}{l}\text { occurrence of an accident } \\
\text { during take-off }\end{array}$ & 6 & 1 & 20 & 20 & 98 & 83 & $\mathrm{~N}$ & $\mathrm{~N}$ \\
\hline 8. & damage during takeoff & 6 & 1 & 5 & 1 & 30 & 15 & $\mathrm{~T}$ & $\mathrm{~A}$ \\
\hline 9. & $\begin{array}{l}\text { the occurrence of an } \\
\text { accident during the flight }\end{array}$ & 6 & 1 & 20 & 20 & 98 & 43 & $\mathrm{~N}$ & $\mathrm{~N}$ \\
\hline 10. & occurrence of fuel shortage & 3 & 0.1 & 10 & 5 & 39 & 20.3 & $\mathrm{~T}$ & $\mathrm{~T}$ \\
\hline 11. & $\begin{array}{l}\text { unintentional entry into the } \\
\text { tailspin }\end{array}$ & 6 & 1 & 1 & 5 & 30 & 21 & $\mathrm{~T}$ & A \\
\hline 12. & $\begin{array}{l}\text { occurrence of collision with } \\
\text { birds during landing }\end{array}$ & 6 & 1 & 5 & 5 & 38 & 23 & $\mathrm{~T}$ & A \\
\hline 13. & $\begin{array}{l}\text { occurrence of an incident } \\
\text { during landing }\end{array}$ & 6 & 1 & 5 & 5 & 38 & 23 & $\mathrm{~T}$ & A \\
\hline 14. & $\begin{array}{l}\text { occurrence of an accident } \\
\text { during landing }\end{array}$ & 6 & 1 & 20 & 20 & 98 & 43 & $\mathrm{~N}$ & $\mathrm{~N}$ \\
\hline
\end{tabular}

Based on a checklist of questions about the occurrence of sources, 37 hazards were formulated in the area of general aviation flight in the uncontrolled space in accordance with the VFR rules. From them, 6 are characterized by the category of unaccepted risk, and 15 are categorized as tolerated. It was noticed that in the majority of hazards the source of danger may be a poor psychophysical state of the 
pilot. In as many as 30 out of 37 threats $(80 \%)$ such source was located. Therefore, as a method of dealing with risk, a system can be proposed that monitors the psycho-physical state of the pilot and helps him in the situation of a shortage of cognitive resources. After the assumptions were made and the assumed positive results were taken into account, another risk assessment was carried out - after the proposed system was applied. The application of this assumption allowed to reduce the level of $K_{1}$ for fourteen threats. The results presented in this paper were limited to hazards in which the risk was limited (Table 1). The analyzes have shown that the implementation of the proposed system may contribute to reducing the risk in 14 of 37 (about $40 \%$ ) previously formulated hazards. The re-evaluation indicated that 27 of them belong to the accepted category, 6 classified as tolerated and 6 as unacceptable.

\section{Summary and conclusions}

The use of risk estimation and evaluation methods dedicated to the area of flight with visibility in the uncontrolled space is a proactive approach to safety management facilitating the identification of critical areas for which it is necessary to apply measures to reduce the risk of threats.

However, currently used methods are dedicated to areas significantly deviating from the specific issue of air operations, especially in uncontrolled space. It is reasonable to adapt these methods to selected areas of analysis (e.g, flight with visibility in an uncontrolled space) or to develop a new method. Adapting risk estimation and evaluation methods for a selected area of analysis should primarily consist in changing the degree of damage that is generated by an adverse event. In air transport systems, it is therefore appropriate to introduce a classification of damage compatible, for example, with the provisions on accident and incident investigation (i.e., incident, serious incident and accident).

\section{References}

1. http://essi.easa.europa.eu/

2. http://ulc.gov.pl/

3. Instructions for Use in Flight for Cessna 152.

4. Lewandowski P.A.: Statystyka Zdarzeń Lotniczych 2015/2016. Państwowa Komisja Badania Wypadków Lotniczych, 2016.

5. Majchrzak E., Bliżej Europy. Samolot dla biznesu. Poradnik przedsiębiorcy, 127(11), 2012. 
6. Merkisz J., Galant M.: Risk management of hazards for route between Lawica Kobylnica - Bednary airports. Journal of KONBiN, 2(22), 2012, DOI 10.2478/jok2013-0029.

7. Merkisz J., Markowski J., Galant M., Karpiński D.: Ocena ryzyka zagrożeń na stanowisku koordynatora ruchu lotniczego naziemnego $\mathrm{w}$ modelowym porcie lotniczym. Technika Transportu Szynowego, No. 10, 2013.

8. Rutkowski A.: Ile latamy? Statystyki FIS. Przegląd Lotniczy, Aviation Revue, Warszawa 2016.

9. Ustawa z dnia 3 lipca 2002 r. Prawo Lotnicze (Dz.U. $2002 \mathrm{Nr} 130$ poz. 1112). Warszawa, Kancelaria Sejmu, 2002. 


\section{OCENA RYZYKA ZAGROŻEŃ W LOCIE W PRZESTRZENI NIEKONTROLOWANEJ WEDLUG PRZEPISÓW DLA LOTÓW Z WIDOCZNOŚCIĄ VFR}

\section{Wprowadzenie}

Transport lotniczy jest najmłodszą i najbardziej dynamicznie rozwijającą się gałęzią transportu. Jego rozwój nie dotyczy jednak jedynie przewozów zarobkowych pasażerskich i towarowych. Coraz więcej uwagi i zainteresowania poświęca się lotnictwu rekreacyjnemu i sportowemu. Lotnictwo ogólne stało się praktycznie powszechnie dostępne. Wzrastający ruch w okolicach lotnisk generuje potrzebę zapewnienia realizacji procesów żeglugi powietrznej przy akceptowanym lub przynajmniej tolerowanym ryzyku zagrożeń w coraz bardziej złożonym środowisku zarządzania ruchem lotniczym. Obowiązujące przepisy wymagają opracowywania systemów zarządzania bezpieczeństwem w organizacjach lotniczych (SMS) oraz opracowania i wdrożenia Krajowego Programu Bezpieczeństwa (SSP) w państwie.

Analiza liczby zdarzeń wykazała zdecydowane różnice pomiędzy zarobkowym transportem lotniczym (ang. Commercial Air Transport, CAT), a lotnictwem ogólnym (ang. General Aviation, GA). Na podstawie danych ULC i PKBWL zauważono, że $[2,4]$ :

- 90-100\% wypadków lotniczych ma miejsce w sektorze GA,

- 65-75\% poważnych incydentów ma miejsce w sektorze GA,

- 70-75\% incydentów ma miejsce w sektorze CAT,

- 80-90\% zgłoszeń generowanych jest w sektorze CAT.

Postanowiono zatem ograniczyć obszar analiz do sektora GA. Przyjmuje się, że obejmuje on cały ruch lotniczy (prywatny i komercyjny) z wyłączeniem lotów rozkładowych oraz wojskowych [5]. W Załączniku 6 do Konwencji o Międzynarodowym Lotnictwie Cywilnym istnieje jednak zapis mówiący o tym, że operacje lotnictwa ogólnego (general aviation operation) są to operacje $\mathrm{z}$ wykorzystaniem statków powietrznych, inne niż te wykonywane w ramach zarobkowego transportu lotniczego lub w ramach usług lotniczych. Szczegółową klasyfikację GA prowadzi Europejski Zespół ds. Bezpieczeństwa Lotnictwa Ogólnego (ang. European General Aviation Safety Team, EGAST), będący jednym 
z filarów Europejskiej Strategicznej Inicjatywy na rzecz Bezpieczeństwa (ang. European Strategic Safety Initiative, ESSI), działającej przy Europejskiej Agencji Bezpieczeństwa Lotniczego EASA. Zespół zaznacza, że lotnictwo ogólne jest rozproszoną i rozległą społecznością tworzoną przez bardzo różnorodne składowe, jak lotnictwo biznesowe, prace powietrzne, lotnictwo sportowe (wyczynowe) czy lotnictwo rekreacyjne [1]. W lotnictwie sportowym i rekreacyjnym można dodatkowo wyróżnić loty samolotów, balonów, szybowców, samolotów ultralekkich, a także spadochronów czy lotni oraz sky-surfing.

Loty GA, w przeciwieństwie do rozkładowych, mogą odbywać się nie tylko w przestrzeni kontrolowanej, ale również w niekontrolowanej. Prowadzi to do trudności w pełnym zobrazowaniu skali ruchu lotniczego w tym sektorze, ponieważ nie jest wymagane składanie planu lotu i raportu po jego wykonaniu. Jedynym miarodajnym wskaźnikiem rozwoju lotnictwa w przestrzeni niekontrolowanej są zatem statystyki Służby Informacji Powietrznej (ang. Flight Information Services, FIS). Należy jednak pamiętać, że pilot nie ma obowiązku nawiązywania łączności ze służbą, stąd niemożliwe jest oszacowanie rzeczywistej liczby operacji lotniczych. Polska Agencja Żeglugi Powietrznej (PAŻP) w swoich statystykach zlicza operacje lotnicze rozumiane jako odnotowanie korespondencji w dowolnym momencie lotu. Nie rozdziela się zatem startów i lądowań czy chwilowych wyjść ze strefy niekontrolowanej. Corocznie służba FIS obsługuje około 200 tys. lotów [8]. Rejon informacji powietrznej FIR Warszawa (ang. Flight Information Region) podzielony jest na pięć sektorów FIS. Należą do nich: Poznań, Gdańsk, Warszawa, Olsztyn i Kraków. Największą liczbę operacji w notuje się w sektorze Poznań.

W dalszej części pracy podjęta zostanie próba oceny ryzyka zagrożeń w obszarze analiz, jakim jest lot samolotu lotnictwa ogólnego wykonywany zgodnie z przepisami dla lotów $\mathrm{z}$ widocznością $\mathrm{w}$ przestrzeni niekontrolowanej. Po zaprezentowaniu charakterystyki obszaru analiz dokonana zostanie ocena ryzyka zagrożeń.

\section{Prezentacja obszaru analiz}

Jako obszar analiz przyjęto lot samolotu lotnictwa ogólnego w przestrzeni niekontrolowanej nad terytorium Rzeczpospolitej Polskiej, zgodnie z przepisami dla lotów z widocznością VFR. Obszar analiz podzielono na podobszary, w których identyfikuje się źródła zagrożeń. W obszarze analiz wyodrębniono zatem podobszary takie jak:

- statek powietrzny,

- przestrzeń powietrzna,

- lotnisko aeroklubowe, 
- służba informacji powietrznej,

- pilot.

\section{Statek powietrzny}

W Polsce, na mocy postanowień ustawy z dnia 3 lipca 2002 r. Prawo Lotnicze spis statków powietrznych prowadzi Prezes Urzędu Lotnictwa Cywilnego [9]. Rejestr statków powietrznych obejmuje samoloty, śmigłowce, szybowce, motoszybowce, sterowce, balony i bezzałogowe statki powietrzne o masie przekraczającej $25 \mathrm{~kg}$ [9]. Na początku stycznia 2019 r. w polskim rejestrze było 2748 statków powietrznych (SP), a dalszych 1038 w ewidencji. Rocznie liczba SP wpisanych do rejestru zwiększa się o ok. $3 \%$. Z uwagi na wybrany obszar badań dalszej analizie poddano statki powietrzne najczęściej używane w polskim lotnictwie ogólnym. Na podstawie analizy danych z rejestru uznano, że najczęściej użytkowanym w Polsce samolotem jest samolot Cessna - modele 150 i 152. Oba te modele są do siebie bardzo zbliżone - są to jednosilnikowe, dwumiejscowe, metalowe górnopłaty zastrzałowe przystosowane do ogólnego użytkowania, wyposażone w stałe trójkołowe podwozie z kołem przednim [3]. Występują nieznaczne różnice wizualne i techniczne. Z punktu widzenia analizy bezpieczeństwa różnice te są na tyle niewielkie, iż mogą zostać uśrednione, a analiza będzie poprawna dla obu typów statków powietrznych. Na podstawie Instrukcji Użytkowania w Locie [3] określono źródła zagrożeń dotyczące wybranego statku powietrznego.

\section{Przestrzeń powietrzna}

Zgodnie z ustawą Prawo Lotnicze polska przestrzeń powietrzna podzielona jest na przestrzeń kontrolowaną i niekontrolowaną [9]. Analizowany lot ma miejsce poniżej FL095, a więc w przestrzeni niekontrolowanej. Ma ona klasę G, co oznacza, że separacja nie jest zapewniona dla żadnych lotów, dostępna jest jednak służba informacji powietrznej. W procesie rozpoznawania źródeł zagrożeń szczególnie istotne będą elastyczne struktury w przestrzeni. Zalicza się do nich: strefy zakazane (P), strefy niebezpieczne (D), strefy ograniczone (R), strefy czasowo wydzielone (TSA), strefy czasowo rezerwowane (TRA) oraz rejony ćwiczeń (EA).

Przepisy dzielą procedury wykonywania lotów na: loty z widocznością VFR (ang. Visual Flight Rules) oraz loty według wskazań przyrządów IFR (ang. Instrument Flight Rules). Loty VFR muszą odbywać się z zachowaniem ściśle określonych w przepisach zasad, dotyczących warunków meteorologicznych VMC (ang. Visual Meteorological Conditions) oraz sposobu wykonywania tego rodzaju lotów. Niedopuszczalna jest utrata widoczności powierzchni Ziemi. W lotach aeroklubowych zdecydowanie częściej wykonuje się loty VFR - stąd ich wybór do dalszych analiz. 


\section{Lotnisko aeroklubowe}

W Rejestrze Lotnisk Cywilnych widnieją 62 pozycje: lotniska użytku publicznego certyfikowane (14), lotniska użytku publicznego o ograniczonej certyfikacji (8), lotniska użytku publicznego niepodlegające certyfikacji (21) oraz lotniska użytku wyłącznego (19). Na potrzeby analiz postanowiono nie ograniczać się do konkretnego lotniska czy lądowiska. Analizy będą przeprowadzone dla ogólnego zarysu modelowego lotniska aeroklubowego. Dzięki takiemu zabiegowi zachowana zostanie uniwersalność analizy w przypadku wykorzystania modelu w innych warunkach.

\section{Służba Informacji Powietrznej FIS}

Państwowym organem odpowiedzialnym za zarządzanie krajową przestrzenią powietrzną (FIR Warszawa) jest PAŻP. Zgodnie z ustawą Agencja zapewnia bezpieczną, ciągłą, płynną i efektywną żeglugę powietrzną w polskiej przestrzeni powietrznej przez zapewnianie służby żeglugi powietrznej, zarządzanie przestrzenią powietrzną oraz zarządzanie przepływem ruchu lotniczego.

W przestrzeni niekontrolowanej pilotom statków powietrznych zapewniona jest bezpłatnie służba informacji powietrznej FIS. Służba pełniona jest dla lotów VFR jak i IFR przez całą dobę. Korzystanie $\mathrm{z}$ niej nie zwalnia pilota-dowódcy statku powietrznego z żadnej odpowiedzialności i do niego należy ostateczna decyzja co do proponowanej zmiany planu lotu. Służba informacji powietrznej zapewnia informacje przydatne w wykonywaniu lotów oraz inne informacje mogące mieć wpływ na bezpieczeństwo. FIS nie zapewnia separacji statków powietrznych, jednak może udzielić informacji o innym ruchu lotniczym w pobliżu lecącego statku powietrznego. Nawiązywanie łączności z FIS nie jest obowiązkowe.

\section{Pilot}

W celu scharakteryzowania grupy użytkowników lotnictwa ogólnego posłużono się Raportem ilości ważnych licencji wydanym przez Rejestr Personelu Lotniczego operujący przy ULC [2]. Jako reprezentatywne wybrano grupy pilotów turystycznych (PPL) i rekreacyjnych (LAPL) uprawnionych do pilotowania samolotów. Na koniec 2018 r. liczba ważnych licencji wynosiła odpowiednio 4854 i 29. Urząd Lotnictwa Cywilnego nie prowadzi jednak statystyk dotyczących wieku pilotów uprawnionych do lotów. Posiadacz licencji LAPL(A) jest uprawniony do wykonywania czynności pilota dowódcy samolotów jednosilnikowych tłokowych lądowych lub motoszybowców turystycznych o maksymalnej poświadczonej masie startowej $2000 \mathrm{~kg}$ lub mniej, przewożących maksymalnie trzech pasażerów, w taki sposób, że na pokładzie statku powietrznego nigdy nie znajdują się więcej niż cztery osoby [9]. Posiadacz licencji PPL(A) jest uprawniony do wykonywania bez wynagrodzenia czynności pilota dowódcy lub drugiego pilota samolotów lub 
motoszybowców turystycznych w operacjach niekomercyjnych [9]. Należy dodać, że licencja PPL(A) uprawnia do pełnienia bez wynagrodzenia funkcji: pilotadowódcy samolotu nieużywanego za opłatą oraz drugiego pilota - na wszystkich samolotach, które nie są używane odpłatnie. Uprawnienia te dotyczą samolotów jednosilnikowych lądowych o masie startowej do $5700 \mathrm{~kg}$, na zasadach VFR.

\section{Rozpoznanie źródel zagrożeń i formułowanie zagrożeń}

W celu sprawdzenia listy kontrolnej z pytaniami o występowanie źródeł zagrożeń podzielono obszar analizy ryzyka, zgodnie z opisem zawartym w jego charakterystyce. Najwięcej pytań (44) o występowanie źródeł zagrożeń dotyczy pilota statku powietrznego. Odpowiedzi pozytywne można uzyskać zarówno na pytania o stan psychofizyczny pilota, jak i o jego kwalifikacje i umiejętności. Drugą grupą pytań (18) są te związane ze służbami informacji powietrznej FIS, pracownikami lotniska i innymi osobami mogącymi mieć wpływ na bezpieczeństwo lotu. Trzecia, niezwykle istotna grupa pytań (25), dotyczy stanu technicznego statku powietrznego, aktualności przeglądu, utrudnień w kokpicie itp. Z uwagi na fakt, że w obszarze analiz znajduje się modelowe lotnisko, konieczne było zawarcie grupy pytań (20) związanych z dostępną infrastrukturą, ułatwieniami lub utrudnieniami tam występującymi. Ostatnią ze zdefiniowanych grup jest ta dotyczącą warunków środowiskowych (16 pytań). Pod uwagę wzięto tu nie tylko warunki atmosferyczne, ale także możliwość przemysłowego zanieczyszczenia powietrza itp. Generalnie rzecz biorąc, grupa ta dotyczy wszystkich kwestii, na które pilot i ludzie w jego bezpośrednim otoczeniu nie mają wpływu. Rozpoznanie źródeł zagrożeń zostało przeprowadzone przez udzielenie odpowiedzi na pytania zawarte w liście pytań kontrolnych. Cała lista zawierała 123 pytania, a jej wycinek (wraz z odpowiedziami) przedstawiono na rys. 1 .

Zgodnie $\mathrm{z}$ algorytmem zarządzania ryzykiem, rozpoznania źródeł zagrożeń dokonano na podstawie wydzielenia $\mathrm{z}$ listy pytań tych, w których odpowiedź znalazła się w polu krytycznym (oznaczonym na błękitno). Lista rozpoznanych źródeł zagrożeń zawiera 99 pozycji. Na jej podstawie możliwe było sformułowanie zagrożen. Przez zagrożenie rozumie się warunkową możliwość ujawnienia się strat w wyniku aktywizacji źródła zagrożen. Formułowanie zagrożeń można rozumieć więc jako sposób wyrażenia i zapisania zdarzeń mogących przynieść takie straty w obszarze analiz.

Zdefiniowane zagrożenia podzielono na sześć grup:

- zagrożenia związane bezpośrednio z pilotem (5 zagrożeń),

- zagrożenia występujące przed wykonaniem lotu (7 zagrożeń),

- zagrożenia związane z fazą startu SP (4 zagrożenia),

- zagrożenia związane z fazą lotu SP (13 zagrożeń), 
- zagrożenia związane z fazą lądowania SP (6 zagrożeń),

- zagrożenia występujące po wykonaniu lotu (2 zagrożenia).

\begin{tabular}{|c|c|c|c|}
\hline \multirow{2}{*}{ Lp. } & \multirow{2}{*}{ Pytania kontrolne o występowanie źródel zagrożeń } & \multicolumn{2}{|c|}{ Odpowiedź } \\
\hline & & TAK & NIE \\
\hline \multicolumn{4}{|c|}{ GRUPA PYTAŃ 1 - PILOT } \\
\hline 1.1 & $\begin{array}{l}\text { Czy istnieje możliwość, że pilot nie jest w dobrej kondycji } \\
\text { psychofizycznej? }\end{array}$ & $\mathbf{X}$ & \\
\hline \multicolumn{4}{|c|}{ 年 } \\
\hline 1.44 & $\begin{array}{l}\text { Czy istnieje możliwość zmiany parametrów lotu w wyniku } \\
\text { nieświadomego działania pilota? }\end{array}$ & $\mathbf{X}$ & \\
\hline \multicolumn{4}{|c|}{ GRUPA PYTAŃ 2 - SŁUŻBA FIS } \\
\hline 2.6 & $\begin{array}{l}\text { Czy istnieje możliwość braku zrozumienia komunikatów pomiędzy } \\
\text { pilotem a FIS? }\end{array}$ & $\mathbf{X}$ & \\
\hline$\ldots$ & & & \\
\hline \multicolumn{4}{|c|}{ GRUPA PYTAŃ 4 - INFRASTRUKTURA LOTNISKA } \\
\hline \multicolumn{4}{|c|}{ 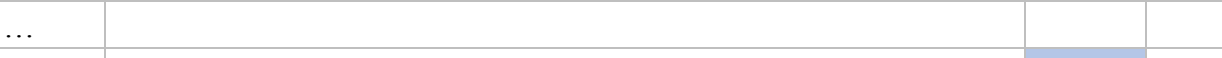 } \\
\hline 4.4 & Czy istnieje możliwość zderzenia się z przeszkodą podczas startu? & & $\mathbf{X}$ \\
\hline 4.5 & $\begin{array}{l}\text { Czy istnieje możliwość zderzenia się z przeszkodą podczas } \\
\text { kołowania? }\end{array}$ & $\mathbf{X}$ & \\
\hline 4.6 & Czy istnieje pewność, że przeszkody lotniskowe są dobrze oznakowane? & $\mathbf{X}$ & \\
\hline$\ldots$ & & & \\
\hline
\end{tabular}

Rys. 1. Elementy listy kontrolnej pytań o występowanie źródeł zagrożeń

\section{Szacowanie i wartościowanie ryzyka}

Do oceny ryzyka zagrożeń wybrano metodę MICE-RISK. Jest to autorska, jakościowa metoda oceny ryzyka, pozwalająca na szczegółowe określenie jego poziomu, z uwzględnieniem zarówno prawdopodobieństwa wystąpienia zdarzenia, jak i strat, jakie może generować jego wystąpienie [6,7]. Dla każdego zdefiniowanego zagrożenia zostały przypisane odpowiednie zmienne charakteryzujące poziom prawdopodobieństwa pojawienia się szkody oraz poziom szkód generowanych przez aktywizację zagrożenia. Przykład szacowania ryzyka zagrożeń w locie z widocznością w przestrzeni niekontrolowanej zaprezentowano poniżej.

Zagrożenie: Możliwość zasłabnięcia pilota wywołana jego złym stanem

Zmienne: $\mathrm{K}_{1}=3 ; \mathrm{K}_{2}=5 ; \mathrm{K}_{3}=5$

Obliczenie wartości wskaźnika ryzyka: 29 
Poziom ryzyka: istotne

Kategoria ryzyka: tolerowane

Wśród zdefiniowanych zagrożeń, trzy osiągnęły poziom ryzyka określony jako bardzo duży, trzy - duży, 15 - poziom istotny, 12 - poziom określony jako mały, a cztery - poziom pomijalny. Po kategoryzacji ryzyka osiągnięto następujące wyniki: 16 zagrożeń mieści się w kategorii „akceptowane”, 15 zagrożeń cechuje kategoria „tolerowane”, a dla sześciu kategorię określono jako nieakceptowaną. Ryzyko nieakceptowane jest to obszar ryzyka, przy którym pod żadnym względem nie powinno się dopuszczać do funkcjonowania systemu. W przypadku gdy oszacowane ryzyko znajduje się w tej kategorii, należy niezwłocznie podjąć działania prowadzące do jego ograniczenia. Jeżeli oszacowane ryzyko znajduje się w kategorii ryzyka tolerowanego, należy podjąć działania zapobiegawcze, zmierzające do redukcji ryzyka lub usunięcia źródeł zagrożenia, a poziom ryzyka powinien być monitorowany. Ryzyko akceptowane jest to obszar ryzyka niewiele znaczącego lub akceptowanego bez konieczności podejmowania działań zmniejszających, można zaprzestać działania redukujące jego poziom, ale dalej powinna być prowadzona kontrola (monitorowanie) ryzyka [7].

\section{Postępowanie wobec ryzyka}

Ostatnim krokiem w algorytmie zarządzania ryzykiem jest postępowanie wobec ryzyka. Pod pojęciem tym rozumie się zajęcie aktywnej postawy wobec zagrożeń zidentyfikowanych $\mathrm{w}$ obszarze analiz. W celu doboru odpowiedniego sposobu postępowania wobec ryzyka przeanalizowano wyniki oceny ryzyka.

$\mathrm{Na}$ podstawie listy kontrolnej pytań o występowanie źródeł zagrożeń, w obszarze lotu samolotu lotnictwa ogólnego w przestrzeni niekontrolowanej zgodnie z przepisami VFR sformułowano 37 zagrożeń. Spośród nich sześć cechuje się kategorią ryzyka nieakceptowanego, a 15 skategoryzowano jako tolerowane. Zauważono, że źródłem większości zagrożeń może być zły stan psychofizyczny pilota. W aż 30 z 37 zagrożeń (80\%) zlokalizowano takie źródło. Dlatego też jako metodę postępowania wobec ryzyka można zaproponować system monitorujący stan psychofizyczny pilota i wspomagający go w sytuacji niedoboru zasobów poznawczych. Po opracowaniu założeń i uwzględnieniu zakładanych korzystnych rezultatów przeprowadzono kolejną próbę oceny ryzyka - już po zastosowaniu proponowanego systemu. Zastosowanie wspomnianego założenia pozwoliło na obniżenie poziomu $\mathrm{K}_{1}$ dla 14 zagrożeń. Wyniki przedstawione w niniejszej pracy ograniczono do zagrożeń, w których ograniczono ryzyko (tab. 1). Analizy 
wykazały, że zaimplementowanie proponowanego systemu może przyczynić się do ograniczenia ryzyka w 14 z 37 (ok. 40\%) sformułowanych wcześniej zagrożeń. Ponowna ocena wykazała, że 27 zagrożeń należy do kategorii „akceptowane”, sześć sklasyfikowano jako tolerowane oraz sześć jako nieakceptowane.

Tabela 1

Zestawienie zagrożeń dla których obniżono poziom $K_{1}$ w wyniku zastosowania systemu monitorującego pilota i wspomagającego jego pracę w sytuacji niedoboru zasobów poznawczych, gdzie: A - ryzyko akceptowane, T - ryzyko tolerowane, N - ryzyko nieakceptowane

\begin{tabular}{|c|c|c|c|c|c|c|c|c|c|}
\hline \multirow{2}{*}{ Lp } & \multirow{2}{*}{$\begin{array}{l}\text { Zagrożenie } \\
\text { Możliwość... }\end{array}$} & \multicolumn{2}{|l|}{$\mathbf{K}_{1}$} & \multirow{2}{*}{$\mathbf{K}_{2}$} & \multirow{2}{*}{$\mathbf{K}_{3}$} & \multicolumn{2}{|l|}{$\mathbf{R}$} & \multicolumn{2}{|c|}{$\begin{array}{l}\text { Kategoria } \\
\text { ryzyka }\end{array}$} \\
\hline & & przed & po & & & przed & po & przed & po \\
\hline 1. & $\begin{array}{l}\text { zasłabnięcia pilota } \\
\text { wywołanego jego złym } \\
\text { stanem }\end{array}$ & 3 & 0,1 & 5 & 5 & 29 & 20,3 & $\mathrm{~T}$ & A \\
\hline 2. & $\begin{array}{l}\text { kolizji SP z przeszkodą } \\
\text { naziemną }\end{array}$ & 10 & 3 & 5 & 1 & 42 & 21 & $\mathrm{~T}$ & A \\
\hline 3. & $\begin{array}{l}\text { uszkodzenia cudzego } \\
\text { mienia wskutek błędu pilota }\end{array}$ & 6 & 1 & 5 & 1 & 30 & 15 & $\mathrm{~T}$ & A \\
\hline 4. & $\begin{array}{l}\text { uszkodzenia SP w wyniku } \\
\text { zdarzeń zainicjowanych } \\
\text { przez inne obiekty }\end{array}$ & 6 & 1 & 5 & 1 & 30 & 15 & $\mathrm{~T}$ & A \\
\hline 5. & $\begin{array}{l}\text { wystapienia kolizji dwóch } \\
\text { SP na lotnisku }\end{array}$ & 1 & 0,1 & 20 & 10 & 63 & 60,3 & $\mathrm{~N}$ & $\mathrm{~N}$ \\
\hline 6. & $\begin{array}{l}\text { wystąpienia incydentu } \\
\text { podczas startu }\end{array}$ & 6 & 1 & 5 & 5 & 38 & 23 & $\mathrm{~T}$ & A \\
\hline 7. & $\begin{array}{l}\text { wystąpienia wypadku } \\
\text { podczas startu }\end{array}$ & 6 & 1 & 20 & 20 & 98 & 83 & $\mathrm{~N}$ & $\mathrm{~N}$ \\
\hline 8. & $\begin{array}{l}\text { uszkodzenia SP podczas } \\
\text { startu }\end{array}$ & 6 & 1 & 5 & 1 & 30 & 15 & $\mathrm{~T}$ & A \\
\hline 9. & $\begin{array}{l}\text { wystąpienia wypadku } \\
\text { podczas lotu }\end{array}$ & 6 & 1 & 20 & 20 & 98 & 43 & $\mathrm{~N}$ & $\mathrm{~N}$ \\
\hline 10. & $\begin{array}{l}\text { wystąpienia niedoboru } \\
\text { paliwa }\end{array}$ & 3 & 0,1 & 10 & 5 & 39 & 20,3 & $\mathrm{~T}$ & $\mathrm{~T}$ \\
\hline 11. & $\begin{array}{l}\text { niezamierzonego wejścia w } \\
\text { korkociąg }\end{array}$ & 6 & 1 & 1 & 5 & 30 & 21 & $\mathrm{~T}$ & A \\
\hline 12. & $\begin{array}{l}\text { wystapienia zderzenia z } \\
\text { ptakami w czasie lądowania }\end{array}$ & 6 & 1 & 5 & 5 & 38 & 23 & $\mathrm{~T}$ & A \\
\hline 13. & $\begin{array}{l}\text { wystąpienia incydentu } \\
\text { podczas lądowania }\end{array}$ & 6 & 1 & 5 & 5 & 38 & 23 & $\mathrm{~T}$ & A \\
\hline 14. & $\begin{array}{l}\text { wystąpienia wypadku } \\
\text { podczas lądowania }\end{array}$ & 6 & 1 & 20 & 20 & 98 & 43 & $\mathrm{~N}$ & $\mathrm{~N}$ \\
\hline
\end{tabular}




\section{Podsumowanie i wnioski}

Wykorzystanie metod szacowania i wartościowania ryzyka dedykowanych dla obszaru lotu $\mathrm{z}$ widocznością $\mathrm{w}$ przestrzeni niekontrolowanej jest proaktywnym podejściem w zarządzaniu bezpieczeństwem, ułatwiającym identyfikację obszarów krytycznych, dla których konieczne jest zastosowanie działań ograniczających ryzyko zagrożeń.

Obecnie stosowane metody są jednak dedykowane dla obszarów znacząco odbiegających od specyficznego zagadnienia, jakim są operacje lotnicze, szczególnie $\mathrm{w}$ przestrzeni niekontrolowanej. Uzasadniona jest adaptacja tych metod do wybieranych obszarów analiz (np. lotu z widocznością w przestrzeni niekontrolowanej) lub opracowanie nowej metody. Dostosowanie metod szacowania i wartościowania ryzyka do wybranego obszaru analiz powinno przede wszystkim polegać na zmianie określania stopnia szkód, które generowane są przez zdarzenie niepożądane. W systemach transportu lotniczego zasadne jest zatem wprowadzenie klasyfikacji szkód zgodnej np. z przepisami dotyczącymi badań wypadków i zdarzeń lotniczych (tj. podział na incydent, poważny incydent i wypadek lotniczy).

\section{Literatura}

1. http://essi.easa.europa.eu/

2. http://ulc.gov.pl/

3. Instructions for Use in Flight for Cessna 152.

4. Lewandowski P.A.: Statystyka Zdarzeń Lotniczych 2015/2016. Państwowa Komisja Badania Wypadków Lotniczych, 2016.

5. Majchrzak E., Bliżej Europy. Samolot dla biznesu. Poradnik przedsiębiorcy, 127(11), 2012.

6. Merkisz J., Galant M.: Risk management of hazards for route between Lawica Kobylnica - Bednary airports. Journal of KONBiN, 2(22), 2012, DOI 10.2478/jok2013-0029.

7. Merkisz J., Markowski J., Galant M., Karpiński D.: Ocena ryzyka zagrożeń na stanowisku koordynatora ruchu lotniczego naziemnego w modelowym porcie lotniczym. Technika Transportu Szynowego, No. 10, 2013.

8. Rutkowski A.: Ile latamy? Statystyki FIS. Przegląd Lotniczy, Aviation Revue, Warszawa 2016.

9. Ustawa z dnia 3 lipca 2002 r. Prawo Lotnicze (Dz.U. 2002 Nr 130 poz. 1112). Warszawa, Kancelaria Sejmu, 2002. 